\title{
Effects of ridge tillage on photosynthesis and root characters of rice
}

\author{
Yao Yuan-zhi ${ }^{*}$
}

Rice (Oryza sativa L.) is an important crop and breeding has not been able to improve yield. Root characteristics of hybrid rice 'Zhuliangyou 02' under conventional tillage and ridge tillage were studied in a Calcisols in Huaihua, China, from 2011 to 2013 to find better tillage methods to resolve massive water consumption, improve yield, and enhance productivity of agricultural labor for rice cultivation. Results showed ridge tillage increased photosynthetic parameters such as photosynthetic rate $\left(\mathrm{P}_{\mathrm{N}}\right)$, stomatal conductance $\left(\mathrm{g}_{\mathrm{s}}\right)$, and water use efficiency (WUE). It also significantly enhanced rice root number, root activity, and antioxidant enzyme activities; it also increased effective panicle number and actual yield by $22.12 \%$ and $15.18 \%$, respectively, and enhanced aerenchymae during the early growth stage. Overall, ridge tillage could promote hybrid rice yields by enhancing root absorption, gas exchange, and reducing water consumption. It could be widely used in rice cultivation.

Key words: Oryza sativa, photosynthesis, tillage method, yield.

\section{INTRODUCTION}

Water shortage and uneven spatial distribution are the main factors restricting the production of food crops. Year after year traditional tillage increases soil and water loss and consumes too much energy (De Vita et al., 2007). Some methods, such as no-tillage cultivation and straw mulching, are gradually applied to prevent soil degradation, reduce soil erosion, and increase soil water storage (Wang et al., 2006; 2007). Studies have indicated that no-tillage cultivation can enhance porosity of deep soil (Zhou et al., 2010), improve temperature sensitivity coefficient of soil respiration (Liu et al., 2010), promote root growth, and increase total dry weight of roots and total root length (Feng et al., 2009). In addition, no-tillage cultivation can also significantly increase the number of soil microbe populations and enhance enzymatic activity (Wang et al., 2011) to improve crop yield. Moreover, with the development of cultivation techniques, studies also have shown that no-tillage with straw return is more conducive to $\mathrm{N}$ supply and nutrient accumulation in rice fields (Gu et al., 2009; Yu et al., 2010). Subsoiling tillage can reduce soil bulk density, increase soil permeability (Borghei et al., 2008; Lü et al., 2010), and improve water productivity (ratio of seed yield/water use) (Arora et al., 2011). Rice performance in aerobic culture might be

${ }^{1}$ Huaihua University, Department of Life Sciences, Huaihua, Hunan, 418008, P.R. China. "Corresponding author (yaoyz1234@126.com). Received: 22 June 2014.

Accepted: 17 October 2014.

doi:10.4067/S0718-58392015000100005 improved by genetic manipulation that promotes lateral root branching and rhizogenesis as well as deep rooting (Kato and Okami, 2011) to benefit crop growth and crop yield enhancement.

Rice is one of China's main food crops. It consumes $70 \%$ of total agricultural water, but its water utilization rate is only $40 \%$, far below the level found in developed countries, and wasting a large amount of water. On the other hand, the market economy has significantly impacted agriculture because rural labor migrates to the industrial and service sectors, resulting in abandoned farmland and recessively abandoned fields. In addition, climate anomalies appear more and more frequently where rainfall is below normal and with a concentrated distribution and drought seriously threatens the stability and security of food production. Although the promotion of hybrid rice greatly improves rice yield, hybrid rice is subject to limitations of cytoplasmic male sterility (CMS) that has much lower cytoplasmic polymorphism than indica, japonica, and wild rice; therefore, further potential for substantial yield improvement is small $(\mathrm{Ou}$ et al., 2009). Current urgent issues in rice culture are related to how to resolve massive water consumption in rice cultivation, how to respond to abnormal impacts of climate change on agricultural production, and how to enhance the productivity of agricultural labor. We studied rice ridge culture compared with traditional tillage and detailed the characteristics of the rice root system under the two tillage conditions; we hoped to provide a theoretical application basis for improving crop culture pattern, increasing production, enhancing water use, and saving water resources. 


\section{MATERIALS AND METHODS}

The experiment was carried out in the town of Luyang $\left(27.55^{\circ} \mathrm{N}, 109.98^{\circ} \mathrm{E}\right)$, Zhongfang county $\left(27.44^{\circ} \mathrm{N}\right.$, $\left.109.95^{\circ} \mathrm{E}\right)$, and Yuanling county $\left(28.46^{\circ} \mathrm{N}, 110.39^{\circ}\right.$ E), Huaihua City, Hunan, China. Huaihua City has good conditions for rice cultivation, such as dark brown cohesive soils, suitable temperatures (annual average temperature of $16.4{ }^{\circ} \mathrm{C}$ ), sunshine (1303.5 to $1519.2 \mathrm{~h}$ ), and precipitation (annual average precipitation 1160 to $1450 \mathrm{~mm}$ ). The hybrid rice 'Zhuliangyou 02' under study comes from crossing 'Shu 1S' as the female parent and 'ZR02' as the male parent.

From 2011 to 2013, the field was under dry farming ridge culture for three consecutive years using a dry farming ridge machine at dry field condition. Dry farming was carried out and completed once with a rotary tiller ridging machine. The furrow was $100 \mathrm{~cm}$ wide and the groove $70 \mathrm{~cm}$ wide. The groove was as deep as the plow could reach. The water irrigation level was managed to the ridge plane during planting and fluctuated between 0 and $20 \mathrm{~cm}$ below the ridge plane during other periods, that is, plants were irrigated when the natural water level was 20 $\mathrm{cm}$ below the ridge plane until the ridge plane was reached. In case of drought and water shortage, rice plants naturally entered the upland rice status, thus allowing a natural alternation between dry rice environment and upland rice environment to adapt to the arid environment. After the ripening stage, the rice field was dried naturally; 15000 stumps with 1 to 2 grains per stump were transplanted in a 0.4 ha field starting from the ridge edge. This method was referred to as ridge tillage. Conventional tillage was carried out with a mechanized hydroponic water harrow. Rice plants were transplanted on the plain field with standard water slurry management: transplanting in shallow water, singling seedlings in a moist condition, tillering in thin water, scaffolding seedlings, providing enough water at the booting stage, and strengthening seeds in half dry and half wet conditions. At the ripening stage, the rice field was dried naturally. Each tillage pattern was tested in three plots with approximately $100 \mathrm{~m}^{2}$ per plot. Ridges between each plot were covered with film to prevent water leakage. Plots were arranged randomly among the repeat regions.

\section{Measuring gas exchange and recording water usage}

Gas exchange was measured between 09:00 and 11:00 h (Beijing time) in mid-August with a portable photosynthesis system (LI-6400, LI-COR Inc., Lincoln, Nebraska, USA) at the tillering, heading, and maturity stages. The net photosynthetic rate $\left(\mathrm{P}_{\mathrm{N}}\right)$, stomatal conductance $\left(\mathrm{g}_{\mathrm{s}}\right)$, and transpiration rate $(\mathrm{E})$ were measured under $1000 \mu \mathrm{mol} \mathrm{m} \mathrm{m}^{-2} \mathrm{~s}^{-1}$ irradiance, $32 \pm 0.5{ }^{\circ} \mathrm{C}$, and native $\mathrm{CO}_{2}$ concentration. Water use efficiency (WUE, \%) was calculated as follows: $\mathrm{WUE}=\mathrm{P}_{\mathrm{N}} / \mathrm{E}$.

To determine the response to irradiance, $\mathrm{P}_{\mathrm{N}}$ was measured at the photosynthetic photon flux density
(PPFD) of 2000, 1800, 1600, 1400, 1200, 1000, 800, $600,400,200,100,50,25$, and $0 \mu \mathrm{mol} \mathrm{m}^{-2} \mathrm{~s}^{-1}$ from a $\mathrm{Li}$-Cor LED irradiation source. The concentration of $\mathrm{CO}_{2}$ was kept at $400 \mu \mathrm{mol} \mathrm{mol}^{-1}$ with a $\mathrm{Li}-\mathrm{Cor} \mathrm{CO}_{2}$ injection system. Leaf temperature was $32 \pm 0.5^{\circ} \mathrm{C}$.

The amount of water used was calculated based on the amount of rainfall provided by the meteorological station and the amount of artificial irrigation water in 2011.

\section{Root numbers}

Three plants per plot were completely dug out during the tillering, heading, and maturity stages, respectively. After being washed carefully, the underground parts were placed on coordinate paper and the number of roots per plant at 10,20 , and $30 \mathrm{~cm}$ height was calculated, respectively. These roots were washed again. After removing impurities and dead roots, roots were dried and weighed. The mean weight of a total of 27 plants from three plots with three plants per plot during tillering, heading, and maturity stages was used for comparison.

\section{Root activities and enzyme activities and light microscopy}

Root activity was measured by the triphenyltetrazolium chloride (TTC) method according to Ou et al. (2011). Catalase (CAT), superoxide dismutase (SOD), peroxidase (POD), and malondialdehyde (MDA) were measured with commercial kits (Nanjing Jiancheng Bioengineering Institute, Nanjing, China).

Primary roots from the tillering and heading stages were fixed in FAA solution (37\% formalin:glacial acetic acid: $50 \%$ ethanol $=5: 5: 90)$. Samples were initially infiltrated with a vacuum at room temperature for 2 $\mathrm{h}$ and then preserved in FAA at room temperature. Samples were pre-stained with Ehrlich's hematoxylin, dehydrated in a graded ethanol series, embedded in paraffin, and then sectioned (8-mm thickness) with a rotary microtome (Leica RM2016, Leica Microsystems, Wetzlar, Germany). All sections were photographed with an Olympus BH60 microscope equipped with a chargecoupled device.

\section{Biomass measurement and yield and yield components}

Samples were collected during the tillering, heading, and maturity stages. To facilitate root sampling, a rectangular hole was dug with a length from the midline between the $1^{\text {st }}$ and the $2^{\text {nd }}$ plants to the midline between the $2^{\text {nd }}$ and the $3^{\text {rd }}$ plants, with a width of half the spacing, and depth of $60 \mathrm{~cm}$; three consecutive plants in the same row in the rectangular hole were collected. After being washed with water, impurities and dead roots were removed. Then the remaining roots and the ground parts of the plants were dried and weighed. The crown:root ratio was calculated. The mean weight of a total of 27 plants from three plots with three plants per plot during the tillering, heading, and maturity stages was used for comparison. 
At harvest, three $24 \mathrm{~m}^{2}$ quadrants of each plot for each treatment were investigated for effective panicle number, grain yield, and grain moisture content. Grain yield at $14 \%$ moisture content was calculated. Meanwhile, 10 ears per plot were sampled to examine grain number and 1000-grain weight.

\section{Statistical analysis}

Parametric data were analyzed with Excel 2003 and SPSS 13.0 (IBM Corporation, Armonk, New York, USA). $\mathrm{P}$-values less than 0.05 were considered significant and highly significant.

\section{RESULTS AND DISCUSSION}

\section{Water utilization}

According to the meteorological statistics of Huaihua City, total precipitation was $111.5 \mathrm{~mm}$ from 2 to 6 June 2011 and $50 \%$ of the water flowed into the furrows. Transplanting started at this time. During transplanting, precipitation was $46.7 \mathrm{~mm}$ on 10 June and $129.3 \mathrm{~m}^{3}$ water $\mathrm{ha}^{-1}$ was stored in the rice field. Precipitation was $160 \mathrm{~mm}$ from 14 to 30 June due to repeated rainfall and $162 \mathrm{~m}^{3}$ water ha ${ }^{-1}$ was stored in the rice field. The total amount of water stored in the rice field reached $257 \mathrm{~m}^{3} \mathrm{ha}^{-1}$ in June. Water stored in the furrows was consumed from 20 June to 4 July. On 4 July, $80 \mathrm{~m}^{3}$ were irrigated. Water was totally consumed on 20 July with water consumption of $5.3 \mathrm{~m}^{3}$ $\mathrm{d}^{-1} \mathrm{ha}^{-1}$ at that temperature. Precipitation was $40 \mathrm{~mm}$ on 27 July, that is, $27 \mathrm{~m}^{3}$ water ha-1 that was consumed within $17 \mathrm{~d}$. Based on $5.3 \mathrm{~m}^{3}$ daily water consumption, a total $132 \mathrm{~m}^{3}$ was needed for the $25 \mathrm{~d}$ from 20 July to 13 August. Precipitation during that period was $27 \mathrm{~m}^{3}$, thus a total of $105 \mathrm{~m}^{3}$ water was saved. On 13 August, $30 \mathrm{~m}^{3}$ water ha ${ }^{-1}$ was irrigated. This period was the heading and flowering stages that required $120 \mathrm{~m}^{3}$ water supply in $20 \mathrm{~d}$ under traditional farming conditions. Under dry farming ridge conditions, $90 \mathrm{~m}^{3}$ was saved during this period. Thus, a total of $355 \mathrm{~m}^{3}$ water was saved. If the calculation is based on the conventional amount of irrigation water of $650 \mathrm{~m}^{3}$ $\mathrm{ha}^{-1}$ that is required quarterly in Southern China, a total of $520 \mathrm{~m}^{3}$ water was saved. After deducting precipitation of $190 \mathrm{~m}^{3}$ in June, $330 \mathrm{~m}^{3}$, approximately $50 \%$, of water was saved by ridge culture.

\section{Photosynthetic characteristics}

The $\mathrm{P}_{\mathrm{N}}$ increased or decreased with irradiance under the two tillage conditions and showed "midday depression"; it was significantly higher in rice under ridge culture than in plants under conventional tillage (Figure 1A). Under a natural $\mathrm{CO}_{2}$ concentration, $\mathrm{P}_{\mathrm{N}}$ increased as the irradiance increased and it was significantly higher in rice under ridge culture than in plants under conventional tillage at the same irradiance (Figure $1 \mathrm{~B}$ ). The values for $\mathrm{P}_{\mathrm{N}}, \mathrm{g}_{\mathrm{s}}$, and $\mathrm{E}$ at all tested stages were significantly higher in rice under ridge culture than in plants under conventional tillage (Table 1). These data indicated that rice could maintain high $\mathrm{P}_{\mathrm{N}}$ by increasing $\mathrm{g}_{\mathrm{s}}$ under ridge culture.
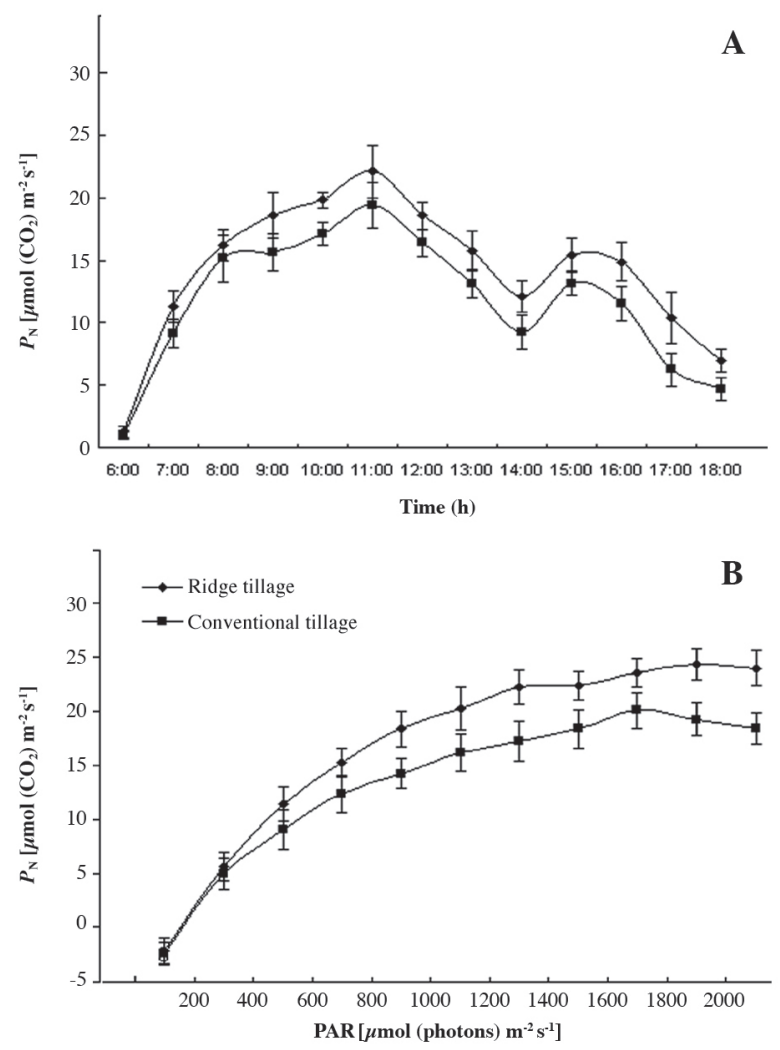

PAR: Photosynthetically active radiation.

Figure 1. Photosynthesis curve for one day (A) and photosynthetic rate $\left(P_{N}\right)$ of rice under different irradiances $(B)$ and tillage methods.

Table 1. Photosynthetic rate $\left(\mathbf{P}_{\mathrm{N}}\right)$, stomatal conductance $\left(\mathrm{g}_{\mathrm{s}}\right)$, transpiration rate $(\mathrm{E})$, and water use efficiency (WUE) of rice at three different growth stages under two different tillage methods.

\begin{tabular}{|c|c|c|c|c|c|}
\hline Stage & Treatment & $\mathrm{P}_{\mathrm{N}}$ & $\mathrm{g}_{\mathrm{s}}$ & $\mathrm{E}$ & WUE \\
\hline & & $\mu \mathrm{mol} \mathrm{CO} 2 \cdot \mathrm{m}^{-2} \cdot \mathrm{s}^{-1}$ & $\mathrm{~mol} \mathrm{H}_{2} \mathrm{O} \mathrm{m}^{-2} \mathrm{~s}^{-1}$ & $\mathrm{mmol} \mathrm{m} \mathrm{m}^{-2} \mathrm{~s}^{-1}$ & $\%$ \\
\hline \multirow[t]{2}{*}{ Tillering stage } & Conventional tillage & $19.87 \pm 1.65 b$ & $0.438 \pm 0.08 b$ & $8.87 \pm 0.75 a$ & $2.24 \pm 0.31 b$ \\
\hline & Ridge tillage & $22.63 \pm 1.46 \mathrm{a}$ & $0.536 \pm 0.06 \mathrm{a}$ & $8.99 \pm 0.86 a$ & $2.55 \pm 0.38 \mathrm{a}$ \\
\hline \multirow[t]{2}{*}{ Heading stage } & Conventional tillage & $20.35 \pm 1.22 b$ & $0.453 \pm 0.05 b$ & $8.76 \pm 0.54 a$ & $2.32 \pm 0.49 b$ \\
\hline & Ridge tillage & $23.32 \pm 0.97 \mathrm{a}$ & $0.565 \pm 0.04 a$ & $8.54 \pm 0.46 a$ & $2.73 \pm 0.38 \mathrm{a}$ \\
\hline \multirow[t]{2}{*}{ Maturity stage } & Conventional tillage & $17.24 \pm 2.36 b$ & $0.389 \pm 0.05 b$ & $9.61 \pm 0.81 \mathrm{a}$ & $1.79 \pm 0.13 b$ \\
\hline & Ridge tillage & $20.35 \pm 1.87 \mathrm{a}$ & $0.503 \pm 0.06 \mathrm{a}$ & $10.06 \pm 0.87 \mathrm{a}$ & $2.02 \pm 0.12 \mathrm{a}$ \\
\hline
\end{tabular}

Lowercase letters indicate significance at 0.05 levels. Means of nine replicates \pm SE. 


\section{Root dry weight and crown:root ratio}

A strong root system is the basis for high yield in rice culture. Root mass could reflect the status of root growth to a certain degree. Rice root dry weight increases with growth. Under ridge tillage, root dry weight was significantly greater than under conventional tillage (Figure 2A). The ratio of rice crown to root showed a rising trend. However, it was not significantly different under the two tillage conditions. It was slightly higher during the tillering stage and lower during the heading and maturity stages under ridge tillage, but the differences did not reach significant levels (Figure 2B). Results indicate that due to fierce nutrient competition under ridge tillage, roots have better growth. In addition, subsoiling

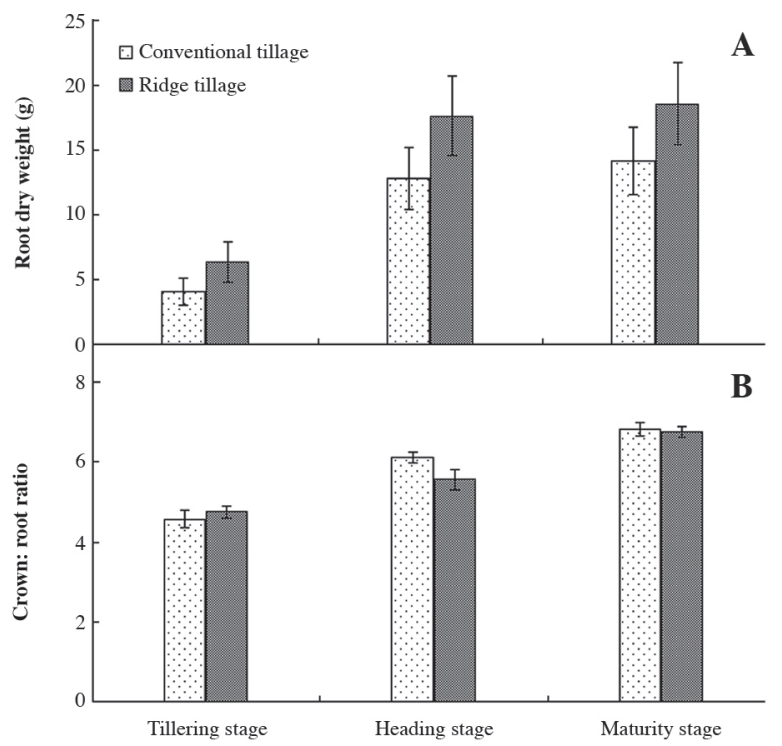

Figure 2. Root dry weight (A) and crown:root ratio (B) of rice at three different growth stages and two tillage methods.

Table 2. Number of rice roots at different growth stages, three soil depths, and different tillage methods.

\begin{tabular}{lllll}
\hline & & \multicolumn{3}{c}{ Number of roots } \\
\cline { 3 - 5 } Stage & Tillage method & $0-10 \mathrm{~cm}$ & $10-20 \mathrm{~cm}$ & $20-30 \mathrm{~cm}$ \\
\hline Tillering stage & Conventional tillage & $328.4 \pm 36.5 \mathrm{~b}$ & $53.8 \pm 5.4 \mathrm{~b}$ & $14.7 \pm 3.5 \mathrm{~b}$ \\
& Ridge tillage & $379.6 \pm 30.3 \mathrm{a}$ & $88.9 \pm 8.6 \mathrm{a}$ & $27.3 \pm 6.5 \mathrm{a}$ \\
Heading stage & Conventional tillage & $366.8 \pm 35.7 \mathrm{~b}$ & $60.2 \pm 6.9 \mathrm{~b}$ & $21.9 \pm 4.5 \mathrm{~b}$ \\
& Ridge tillage & $421.1 \pm 45.4 \mathrm{a}$ & $75.8 \pm 10.3 \mathrm{a}$ & $38.6 \pm 6.2 \mathrm{a}$ \\
Maturity stage & Conventional tillage & $399.1 \pm 27.7 \mathrm{~b}$ & $73.2 \pm 5.2 \mathrm{~b}$ & $29.7 \pm 4.8 \mathrm{~b}$ \\
& Ridge tillage & $506.2 \pm 35.7 \mathrm{a}$ & $89.6 \pm 5.5 \mathrm{a}$ & $46.5 \pm 4.7 \mathrm{a}$ \\
\hline
\end{tabular}

Lower-case letters indicate significance at 0.05 levels. Means of 27 replicates $\pm \mathrm{SE}$ is conducive to root deepening, resulting in a low crownroot ratio at the late heading and maturity stages.

\section{Numbers of roots and root and enzyme activities}

Numbers of total roots and long roots were significantly different under the two tillage conditions. Under ridge tillage, the number of roots increased by $24.92 \%, 19.29 \%$, and $27.950 \%$ during the tillering, heading, and maturity stages, respectively, as compared with conventional tillage. In addition, the number of roots at different soil depths under ridge culture was also higher than under the control, and this difference increased with soil depth (Table 2). Results showed that the rice root system under ridge culture was advanced, which induces nutrient absorption.

Root activity reflects the status of root growth and is an essential indicator for the dynamic relationship between root growth and soil water content and its surrounding environment. Under ridge tillage, root activities during the three developmental stages were significantly higher than those under the control condition, indicating that ridge tillage is better for root growth and nutrient supplementation. In addition, CAT, SOD, and POD activities at various developmental stages were significantly higher under ridge tillage than those under the control condition, suggesting that roots under ridge tillage have a stronger anti-aging ability and ridge tillage is conducive to high yield. The content of MDA, the lipid peroxidation product, is an important index of lipid oxidation and is often used as an indicator of the degree of organ aging. Under ridge tillage, the MDA level was lower than the control during all the development stages, suggesting less membrane lipid oxidation and slower aging under ridge tillage, which helps to extend the fertile period (Table 3 ).

\section{Aerenchyma}

At the tillering stage, root aerenchyma were not obvious under the control condition, but were well-developed under ridge tillage (Figure 3B). At the heading stage, root aerenchyma were more developed, but they were still more advanced under ridge tillage (Figure 3B), indicating ridge tillage is conducive to the formation of root aerenchyma.

\section{Yield and yield components}

Although there were no differences in rice panicle length, number of grains, seed setting rate, and grain weight

Table 3. Root and enzyme activities of rice roots at different growth stages and different tillage methods.

\begin{tabular}{|c|c|c|c|c|c|c|}
\hline \multirow[b]{2}{*}{ Stage } & \multirow[b]{2}{*}{ Tillage method } & \multirow[b]{2}{*}{ Root activity } & \multicolumn{3}{|c|}{ Enzyme activity } & \multirow[b]{2}{*}{ MDA } \\
\hline & & & CAT & SOD & POD & \\
\hline \multirow{3}{*}{ Tillering stage } & & $\mathrm{g} \mathrm{kg}^{-1} \mathrm{~h}^{-1}$ & & $\mathrm{U} \mathrm{mg}^{-1}$ prot & & $\mathrm{nmol} \mathrm{mg}^{-1}$ prot \\
\hline & Conventional tillage & $142.4 \pm 9.3 b$ & $11.8 \pm 1.1 \mathrm{~b}$ & $80.2 \pm 7.2 b$ & $86.9 \pm 8.7 b$ & $3.8 \pm 0.7 \mathrm{a}$ \\
\hline & Ridge tillage & $166.4 \pm 8.8 \mathrm{a}$ & $29.4 \pm 2.5 \mathrm{a}$ & $92.4 \pm 8.7 \mathrm{a}$ & $142.6 \pm 9.7 \mathrm{a}$ & $2.3 \pm 0.4 b$ \\
\hline \multirow[t]{2}{*}{ Heading stage } & Conventional tillage & $167.6 \pm 8.8 b$ & $19.4 \pm 1.5 b$ & $91.4 \pm 7.2 b$ & $96.7 \pm 7.4 b$ & $3.2 \pm 0.2 \mathrm{a}$ \\
\hline & Ridge tillage & $198.5 \pm 11.4 \mathrm{a}$ & $42.7 \pm 2.8 \mathrm{a}$ & $110.6 \pm 9.4 a$ & $165.8 \pm 11.3 \mathrm{a}$ & $2.1 \pm 0.4 b$ \\
\hline \multirow[t]{2}{*}{ Maturity stage } & Conventional tillage & $161.2 \pm 9.4 b$ & $20.9 \pm 1.7 b$ & $86.7 \pm 6.6 b$ & $104.3 \pm 8.5 b$ & $3.5 \pm 0.7 \mathrm{a}$ \\
\hline & Ridge tillage & $187.4 \pm 6.6 a$ & $40.8 \pm 2.4 \mathrm{a}$ & $98.8 \pm 8.3 \mathrm{a}$ & $174.7 \pm 12.1 \mathrm{a}$ & $2.4 \pm 0.4 b$ \\
\hline
\end{tabular}

Lower-case letters indicate significance at 0.05 levels. Means of 10 replicates \pm SE.

CAT: Catalese; SOD: superoroxide dismutase; POD: peroxidase; MDA: malondialdehyde. 

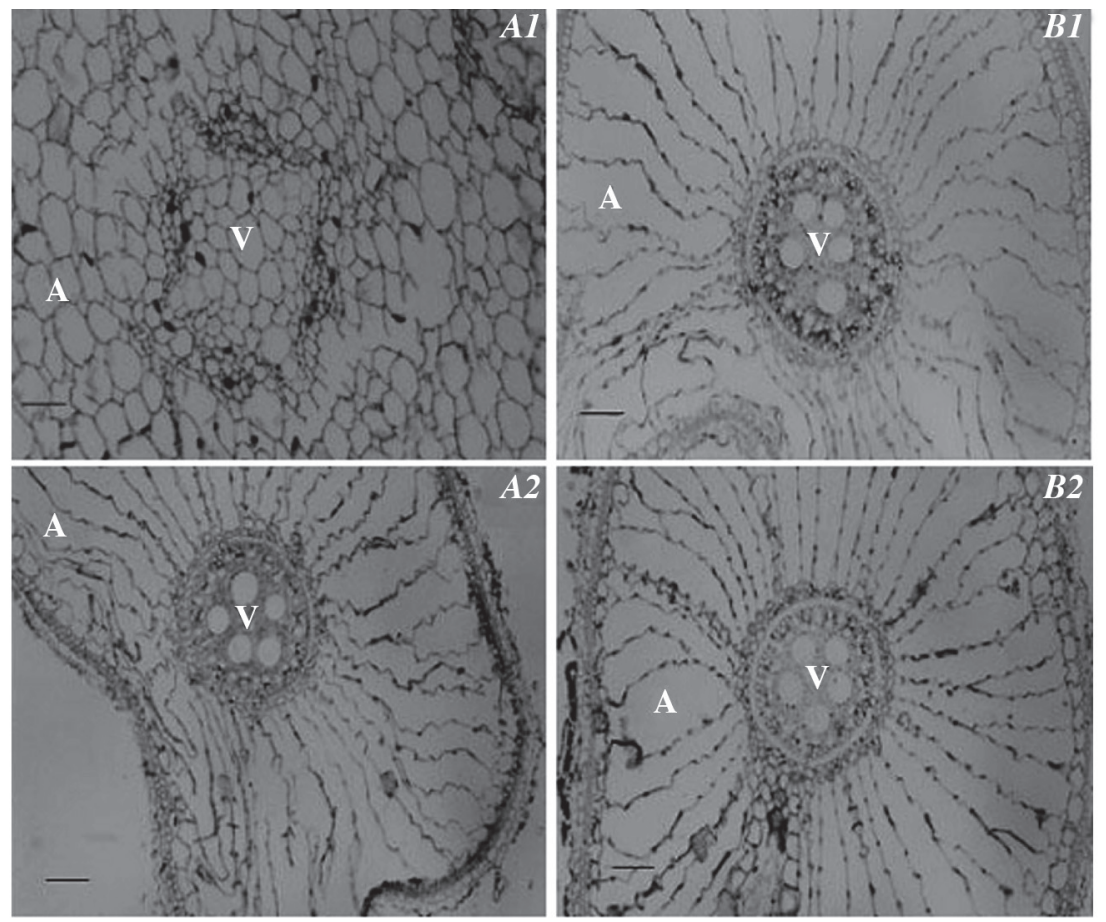

V: vascular; A: aerenchyma. Scale bars: $1 \mu \mathrm{m}$.

Figure 3. Aerenchymae of rice under conventional tillage (A) and ridge tillage (B) at tillering stage (1) and heading stage (2).

under the two tillage conditions, the effective panicle number and actual yield were significantly increased by $22.12 \%$ and $15.18 \%$, respectively, under ridge tillage as compared with conventional tillage (Table 4). Results suggest that different tillage conditions could result in different effective panicle numbers at very significant levels and achieve high yields.

The root system is an important absorption and metabolic organ and an important component of the soilplant system (Sumio, 1985). Root mass can reflect the status of root growth to a certain extent. Water stress will reduce root dry weight (Ruiz-Lau, 2011). The results of this study show that root mass under ridge tillage was significantly greater than under conventional tillage. The number of roots at different soil depths under ridge tillage was also higher than under the control condition; this difference was more obvious at deeper soil depths, which benefits the root system by absorbing more nutrients and has a positive significance on high yield. Root activity is the comprehensive embodiment of root absorptive, synthetic, oxidative, and reductive capacities and could reflect the status of root growth. As a comprehensive indicator of root vitality, it can essentially reflect the dynamic relationship of seedling root growth and soil water content and its surrounding environment (Sechenbater and Wu, 2001; Qu et al., 2002; Li et al., 2010). Our results indicate that ridge tillage could produce part of the root system in a flooded environment and the other part in dry soil environment, which could enhance root activity and induce the root system to maintain its vigorous vitality. In addition, root enzyme activity under ridge tillage is higher than under conventional tillage, which benefits root self-protection and reduction of free radical accumulation and membrane lipid peroxidation.

Panicle number, grain number per panicle, seed setting rate, and grain weight are the main factors of production (Pan et al., 2011). It is currently believed that increasing the tiller rate would easily increase crop yield (Ling, 2000). The cultivation method could impact panicle number $(\mathrm{Wu}$ et al., 2013). Li et al. (2011) compared the features of rice tillering and panicle formation, low productivity, and its contribution to yield under three cultivation conditions: precise artificial transplanting with dry nursery middle and strong seedlings, mechanical transplanting with small

Table 4. Major agronomic characters of rice under different tillage methods.

\begin{tabular}{lcccccc}
\hline Tillage method & Effective panicle & Ear length & Filled grain & Seed setting rate & 1000-grain weight & Actual grain yield \\
\hline & & $\mathrm{cm}$ & & & $\%$ & $\mathrm{~g}$ \\
Conventional tillage & $11.3 \pm 1.8 \mathrm{~b}$ & $28.6 \pm 2.6$ & $153.4 \pm 34.7$ & $77.2 \pm 3.4$ & $27.8 \pm 0.6$ & $446.1 \pm 13.7 \mathrm{~b}$ \\
Ridge tillage & $13.8 \pm 2.4 \mathrm{a}$ & $27.5 \pm 2.8$ & $148.5 \pm 42.1$ & $78.3 \pm 4.1$ & $28.5 \pm 0.5$ & $513.8 \pm 22.5 \mathrm{a}$ \\
\hline
\end{tabular}

Lower-case letters indicate significance at 0.05 levels. Means of 27 replicates \pm SE. 
seedlings, and direct transplanting; they found that the tillering and panicle formation law under different culture conditions is different and increasing the percentage of ear-bearing tillers and panicle number per plant and fully executing the regulation function of tiller group are important for yield improvement. Feng et al. (2011) conducted field experiments of no-tillage and tillage transplanting and found that the former had lower effective panicle number and panicle rate but higher grain weight. Some researchers believed no-tillage had higher yield due to higher effective panicle number and grain weight (Du et al., 1990; Dong et al., 2008). Some researchers also believed that increased effective panicle number is the main reason for improved rice production (Peng et al., 2007; Zhang et al., 2011). We found that ridge tillage could significantly increase tiller number and effective panicle number, but not grain number per panicle, seed setting rate, and grain weight, suggesting that increased panicle number is the major reason for higher yield under ridge tillage, and tillering plays an indispensable role in high-yield group formation and regulation. Based on the above, different culture methods mainly affect panicle number and grain weight. Thus, by increasing grain filling rate, especially that of inferior grains, we can improve grain weight and yield ( $\mathrm{Li}$ et al., 2011). Considering that the seed setting rate and grain filling rate of hybrid rice, especially super hybrid rice, are generally high and the number of inferior grains is small, we believe that the main impact of the farming patterns on yield relies heavily on increased tiller number and effective panicle number.

Rice ridge tillage is designed to improve the soil condition, mitigate drought stress, decrease water consumption, and increase yield by constructing a mixed water and dry binary environment using agricultural machinery. It is easy to operate and suitable for fields with water shortage at early stages, excessively dry field, lowyield farmland, and those fields facilitating the operation of agricultural machinery. Ridge tillage only differs from others by operationally introducing mechanized dry farming ridging techniques. The ridge surface is close to the height of the ridge and the huge furrow could reserve a large amount of water. Thus, it can store water in the rainy season, easing the disadvantages of seasonal rainfall, all the while reducing irrigation times and labor input needed for irrigation. Moreover, ridge tillage could enhance compaction of rice soil, provide structure to dry farming soils, and improve soil respiration.

\section{CONCLUSIONS}

Overall, different tillage methods have different effects on the characteristics of rice photosynthesis and root system. Ridge tillage improves root absorption, strengthens aerenchyma development, and enhances gas exchange by increasing root number, root activity, and enzyme activity, and decreasing membrane lipid damage, which produce increased tiller number, enhanced effective panicles, and eventually higher yield. Meanwhile, ridge tillage can increase water reserves and reduce costs. Therefore, ridge tillage can increase yield as it reduces water consumption, and is worth being promoted.

\section{ACKNOWLEDGEMENTS}

This work was supported by the construct program of the key discipline in Hunan province.

\section{LITERATURE CITED}

Arora, V.K., C.B. Singh, A.S. Sidhu, and S.S. Thind. 2011. Irrigation, tillage and mulching effects on soybean yield and water productivity in relation to soil texture. Agricultural Water Management 98:563-568.

Borghei, A.M., J. Taghinejad, S. Minaei, M. Karimi, and M.G. Varnamkhasti. 2008. Effect of subsoiling on soil bulk density, penetration resistance, and cotton yield in northwest of Iran International Journal of Agricultural Biology 10:120-123.

De Vita, P., E. Di Paolo, G. Fecondo, N. Di Fonzo, and M. Pisante. 2007. No-tillage and conventional tillage effects on durum wheat yield, grain quality and soil moisture content in southern Italy. Soil and Tillage Research 92:69-78.

Dong, A.L., Y.H. Feng, T.J. Zhao, G.G. Han, X.S. Pang, B. Song, et al. 2008. Effects of no-tillage on growth properties and yield in transplanted hybrid rice. Journal of Mountain Agriculture and Biology 27:471-475.

Du, J.Q., S.A. Fang, Z.F. Jiang, W.D. Luo, and C.Q. Zou. 1990. On lo-and no-tillage technique of paddy rice. I. Research in lo-and no-tillage pattern, yield effect and expanded prospects of paddy rice. Southwest China Journal of Agricultural Sciences 3:26-32.

Feng, F.C., G.B. Huang, Q. Chai, A.Z. Yu, H.J. Qiao, and T. Hang. 2009. Effects of different tillage on spatiotemporal distribution of winter wheat root and yield. Acta Ecologica Sinica 29:2499-2506.

Feng, Y.H., Y.B. Zou, and R.J. Buresh. 2011. Effects of no-tillage cultivation on some population characteristics of two-line hybrid rice Liang youpeijiu. Chinese Journal of Rice Science 25:65-70

Gu, M.H., H.P. Qu, X.H. Liu, J. Huang, X.F. Li, L.X. Li, et al. 2009. Characteristics of $\mathrm{N}$ forms and $\mathrm{N}$ transforming bacteria in paddy soil under different tillage. Chinese Journal of Applied Ecology 20:1362-1368

Kato, Y., and M. Okami. 2011. Root morphology, hydraulic conductivity and plant water relations of high-yielding rice grown under aerobic conditions. Annals of Botany 108:575-583.

Li, W.R., S.Q. Zhang, S.Y. Ding, and L. Shan. 2010. Root morphological variation and water use in alfalfa under drought stress. Acta Ecologica Sinica 30:5140-5150.

Li, J., H.C. Zhang, J.L. Gong, Y. Chang, G.C. Wu, Z.H. Guo, et al. 2011. Tillering characteristics and its relationships with population productivity of super rice under different cultivation methods in rice-wheat cropping areas. Acta Agronomica Sinica 37:309-320.

Li, J., H.C. Zhang, J.L. Gong, Y. Chang, Q.G. Dai, Z.Y. Huo, et al. 2011. Influence of planting methods on grain-filling properties of super rice. Acta Agronomica Sinica 37:1631-1641.

Ling, Q.H. 2000. The quality of crop population. p. 107-144. Shanghai Scientific and Technical Publishers, Shanghai, China.

Liu, S., C.H. Yan, W.Q. He, and Q. Liu. 2010. Soil respiration and it's affected factors under different tillage systems in dryland production systems. Acta Ecologica Sinica 30:2919-2924.

Lü, M.R., Z.J. Li, T. Zhang, T.Y. Ning, J.B. Zhao, and H.J. Li. 2010. Effects of minimum or no-tillage system and straw returning on extreme soil moisture and yield of winter wheat. Transactions of the Chinese Society of Agricultural Engineering 26:41-46. 
Ruiz-Lau, N., F. Medina-Lara, Y. Minero-García, E. ZamudioMoreno, A. Guzmán-Antonio, I. Echevarría-Machado, et al. 2011. Water deficit affects the accumulation of capsaicinoids in fruits of Capsicum chinense Jacq. HortScience 46:487-492.

Ou, L.J., X.Z. Dai, Z.Q. Zhang, and X.X. Zou. 2011. Responses of pepper to waterlogging stress. Photosynthetica 49:339-345.

Ou, L.J., G.W. Huang, W.J. Li, G.P. Kang, J.L. Chen, S. Luan, et al. 2009. Chloroplast DNA polymorphism in different types of cytoplasmic male sterile rice. Biologia Plantarum 53:593-596.

Pan, S.G., S.Q. Huang, F. Zhang, J.P. Wang, M.L. Cai, Z.G. Cao, et al. 2011. Growth and development characteristics of super-highyielding mid-season indica hybrid rice. Acta Agronomica Sinica 37:537-544

Peng, Y.X., K.R. Wang, X.L. Xie, and B. Tang. 2007. Effects of rice straw incorporation on soil nitrogen supply and rice yield under different irrigation and fertilizer regimes. Soil and Fertilizer Sciences in China 21:40-43.

Qu, F.N., Y.S. Wang, M. Zhang, L.F. Kang, and J.Y. Yan. 2002. Influence of high temperature stress on root vitality and leaf biochemical indexes of cyclamen. Acta Agriculturae BorealiSinica 17:127-131.

Sechenbater, and H.Y. Wu. 2001. Effect of different stress on roots activity and nitrate reductase activity in Zea mays L. Agricultural Research in the Arid Areas 19:67-70.

Sumio, I. 1985. In situ measurement of rooting density by microrhizotron. Soil Science and Plant Nutrition 31:653-656.
Wang, X.B., D.X. Cai, W.B. Hoogmoed, O. Oenema, and U.D. Perdok. 2006. Potential effect of conservation tillage on sustainable land use: a review of global long-term studies. Pedosphere 16:587-595.

Wang, X.B., D.X. Cai, W.B. Hoogmoed, O. Oenema, and U.D. Perdok. 2007. Developments in conservation tillage in rainfed regions of North China. Soil and Tillage Research 93:239-250.

Wang, J., R.B. Zhang, and T.Y. Zhang. 2011. Effects of conservation tillage on soil microbial physiologies colony and enzyme activities. Journal of Arid Land Resources and Environment 25:168-172.

Wu, H.X., Y.Z. Ma, J.P. Xiao, Z.H. Zhang, and Z.H. Shi. 2013. Photosynthesis and root characteristics of rice (Oryza sativa L.) in floating culture. Photosynthetica 51:231-237.

Yu, L., M. Gao, E. Ci, Z.F. Wang, C.F. Wei, and C. Tu. 2010. Study on the characteristics of mineralization and nitrification in different cultivation modes. Ecology and Environmental Science 19:733-738.

Zhang, S.Q., X.H.Zhong, N.R. Huang, and G.A. Lv. 2011. Effects of straw mulching on dry mater production and grain yield of double cropping late-season rice (Oryza sativa) in south China. Chinese Journal of Rice Science 25:284-290.

Zhou, H., B.G. Li, Y.Z. Lv, J.Y. Zheng, and W.R. Liu. 2010. Multifractal characteristics of soil pore structure under different tillage systems. Acta Pedologica Sinica 47:1094-1100. 